ARTIKEL

\title{
UPAYA MENINGKATKAN KEMAMPUAN BAHASA DAN KOMPETENSI KOMUNIKASI ANTAR PRIBADI DALAM RANGKA MENINGKATKAN PROFEISONALISME KARYAWAN
}

\author{
E. Sulyati \\ STKIP Sebelas April Sumedang \\ e-mail: sulyati@stkip11april.ac.id
}

\begin{abstract}
Abstrak
Perusahaan yang memahami hubungan antara keterlibatan karyawan dan kesuksesan bisnis akan menemukan cara untuk mendorong dan memfasilitasi kesejahteraan emosional pekerja. Salah satu cara untuk mendorong keterlibatan karyawan adalah dengan memberikan pelatihan keterampilan bahasa dan komunikasi antarpribadi. Penelitian ini bertujuan untuk menganalisis apa yang dilakukan oleh perusahaan yang berbasis di Amerika Serikat untuk mencapai tujuan melalui pelatihan keterampilan bahasa dan komunikasi pribadi antara karyawan perusahaan. Metode penelitian ini menggunakan metode kualitatif. Tiga implikasi nyata dari penelitian ini relevan untuk pendidikan bisnis profesional: (a) contoh analisis bisnis yang sebenarnya kegiatan kelas yang berharga, (2) siswa perlu mengenali peran interaksi tempat kerja sehari-hari pada produktivitas dan kepuasan kerja, dan (3) perusahaan mendapat manfaat dari layanan konsultasi ahli di bidang bahasa dan komunikasi bisnis.
\end{abstract}

Kata kunci: Pelatihan Perusahaan, Bahasa, Komunikasi Antarpribadi, Kinerja.

\section{Abstract}

Companies that understand the relationship between employee engagement and business success will find ways to encourage and facilitate the emotional well-being of workers. One way to encourage employee involvement is to provide language skills training and interpersonal communication. This study aims to analyze what is done by a company based in the United States to achieve the goal through language skills training and personal communication between company employees. This research method uses qualitative methods. Three tangible implications of this research are relevant for professional business education: (a) examples of business analysis that are actually valuable classroom activities, (2) students need to recognize the role of daily workplace interactions on productivity and job satisfaction, and (3) the company benefits from consulting services of experts in the fields of language and business communication.

Keywords: Company Training, Language, Interpersonal Communication, Performance.

\section{A. PENDAHULUAN}

Lingkungan kerja telah lama diketahui dapat memberikan efek yang signifikan bagi kinerja karyawan. Sikap pekerja terhadap manajer, rekan kerja, dan organisasi biasanya tercermin dalam output mereka. Amabile \& Kramer (2011) menjelaskan efek keterlibatan karyawan secara rinci. Mereka mempelajari 238 profesional di tujuh perusahaan yang berbeda di tiga industri dan memetakan keadaan psikologis karyawan setiap hari selama 2 tahun, sebagaimana tercermin dalam masukan buku harian elektronik. Analisa mereka mengungkapkan subjek pengaruh kehidupan kerja terhadap persepsi, emosi, dan motivasi 
yang mereka alami pada saat hari kerja. Pembelajaran menemukan bahwa kehidupan kerja karyawan mempengaruhi kinerja pada empat dimensi: kreativitas, produktivitas, komitmen kerja, dan kolegialitas.

Penelitian Herzberg (2008), menunjukkan bahwa motivasi pekerja untuk melakukan pekerjaan secara luar biasa tidak terikat dengan pembayaran atau manfaat. Sebaliknya, Herzberg menemukan bahwa motivasi adalah hasil dari rasa memiliki tempat kerja dan pekerjaan yng menantang yang memungkinkan karyawan untuk mencapai dan merasa diakui.

Penelitian Riketta (2008), menjelaskan studi yang lebih baru yang mengkonfirmasi langsung, hubungan sebab akibat antara kinerja kerja dan faktor-faktor seperti kepuasan, motivasi panggilan, dan sikap positif. Lim et al. (2008), mengambil cara yang berbeda Dalam penelitian mereka, mereka menemukan bahwa ketidaksopanan dan perasaan tidak hormat memberikan efek negatif dalam kepuasan kerja dan sikap terhadap pekerjaan. Disamping mempengaruhi emosi pekerja, hubungan interpersonal dapat memengaruhi jalur karier. Artinya, perusahaan sering menghargai karyawan yang memiliki pengaruh positif pada sikap rekan kerja terhadap pekerjaan.

Sebuah studi oleh Cross \& Parker (2004) menemukan bahwa karyawan yang memberi energi kepada rekan kerja diberi evaluasi kinerja yang lebih baik dan dipromosikan lebih cepat. Reinsch \& Gardner (2011) yang mengutip hasil survei nasional dari eksekutif bisnis senior, menjelaskan bahwa pekerja yang mempunyai keterampilan interpersonal yang kuat lebih dipertimbangkan untuk mendapatkan promosi. Sandelands \& Boudens (2000) menunjukkan bahwa "makna kerja berasal dari hubungan dengan rekan kerja, bukan dari pekerjaan itu sendiri". Mereka menyimpulkan bahwa pekerja berkinerja lebih baik ketika mereka dengan senang hati terlibat dalam apa yang mereka lakukan.

Perusahaan yang mengakui hubungan antara keterlibatan karyawan dan kesuksesan bisnis dapat mencari cara untuk menumbuhkan dan memfasilitasi kesejahteraan emosional pekerja. Salah satu pendekatan untuk mendorong dan mendukung keterlibatan karyawan adalah memberikan pelatihan komunikasi antar pribadi. Membantu karyawan mengembangkan hubungan tempat kerja yamg baik akan memberikan dampak yang bagus untuk bisnis. Tujuan dari penelitian ini adalah untuk menggambarkan apa yang dilakukan oleh satu perusahaan berbasis di AS untuk mencapai tujuan itu.

\section{B. METODE}

Penelitian ini merupakan penelitian kaulitatif. Studi kualitatif dapat memberikan kontribusi yang penting kepada penelitian komunikasi bisnis karena metode penelitian kualitatif dapat menjawab berbagai pertanyaan tentang siapa, apa, kapan, di mana, mengapa, dan bagaimana (Tucker, et al., 1995). Studi ini membahas tentang perusahaan dan komitmennya terhadap pembelajaran dan pengembangan kemampuan karyawan dalam berbahasa dan berkomunikasi. Informasi dikumpulkan selama wawancara yang ekstensif dan berulang selama periode 14 bulan dengan enam pengambil keputusan (seorang perwira senior, dua direktur, seorang kepala departemen, dan dua desainer instruksional). Perusahaan dan evolusi program pelatihan komunikasinya dijelaskan di bawah ini, dengan fokus pada komunikasi antarpribadi komponen. Evaluasi hasil pembelajaran adalah langkah kunci dalam setiap pelatihan atau pendidikan, dan metode evaluasi perusahaan juga diuraikan, bersama 
dengan beberapa temuan. Akhirnya, beberapa implikasi dari studi kasus ini dapat di identifikasi untuk instruktur bisnis perusahaan.

\section{HASIL DAN PEMBAHASAN}

Tim Pembelajaran memutuskan bahwa daripada mencoba menggunakan sumber daya internal, mereka akan melakukannya mencari vendor eksternal, ahli materi pelajaran yang akan bermitra dengan tim menyediakan program yang lebih dinamis. Penulis telah memberikan konsultasi komunikasi dan pelatihan sebagai kontraktor independen dengan perusahaan selama beberapa tahun. Di Desember 2010, seorang manajer senior unit bisnis TI menajukan proposal untuk sebuah modul dalam program pelatihan komunikasi yang sedang dikembangkan.

Fokus modul adalah komunikasi tenaga kerja harian. Tujuan pembelajaran adalah komunikasi yang jelas dan singkat di antara sesama profesional TI serta antara para profesional TI dengan orang-orang lain diluar bagian IT dalam interaksi informal seharihari. saya memulai bekerja menyelesaikan sesi setengah hari yang akan ditawarkan kepada maksimal 20 karyawan. Pengembangan program termasuk meminta ide dan contoh kehidupan nyata dari wawancara dengan manajer departemen. Selama periode ini, saya belajar lebih banyak tentang perusahaan budaya, jargon dan akronim, nilai-nilai, dan tujuan bisnis, jadi saya bisa merujuknya selama program berjalan.

Tanggapan dari para peserta diminta secepatnya setelah postprogram via surveymonkey.com dan juga setelah 60 hingga 90 hari pelatihan. Survei pertama meminta tingkat kepuasan instruktur, materi, topik, dan kegiatan. Juga menanyakan kepada peserta bagian mana dari program yang mereka anggap paling berharga dan perubahan apa yang mereka rekomendasikan. Survei berikutnya mencoba untuk menentukan sejauh mana peserta telah benar-benar mengubah perilaku mereka karena pelatihan.

Karena Tim Belajar menemukan bahwa laporan perubahan perilaku diri bisa jadi bukan merupakan penilaian akurat pelatihan, mereka juga meminta umpan balik dari pengawas peserta pelatihan. Menurut anggota Tim Pembelajaran, anekdot dan cerita tentang perilaku peserta pelatihan dianggap sebagai bukti yang valid dari suatu efektifitas program. Dia menyebut pendekatan ini sebagai metode kasus sukses. Ketika ditanya apakah metode ini dapat dilakukan untuk mengukur hasil di tingkat perusahaan, seperti pengembalian investasi, kata anggota Tim Pembelajaran yang akan sangat sulit untuk diukur.Lebih lanjut, dia mengatakan bahwa rekan sumber daya manusianya yang bekerja di perusahaan lain setuju bahwa melacak efek pelatihan pada retensi, profitabilitas, atau yang serupa metrik tidak praktis, jika bukan tidak mungkin.

Meskipun demikian, karyawan yang berusaha mengubah perilaku mereka setelah menghadiri pelatihan diakui dan dihargai. Komunikasi adalah kompetensi utama dalam ulasan. Jika seorang supervisor menilai seorang karyawan mempunyai performa lebih tinggi dari skala yang telah di tentukan dalam evaluasi kinerja, penilaian ini dapat menyebabkan kenaikan gaji atau mendapatkan promosi. Misalnya, seorang penyelia memuji ide atau gagasan yang berkontribusi selama diskusi pada sebuah rapat, di banding sebelum ikut pelatihan komunikasi yang mana karyawan hanya diam aja.

Pada saat ini, modul komunikasi antar pribadi adalah satu dari empat program pelatihan komunikasi, dengan modul lainnya yang masih dalam tahap pengembangan. Dalam 
rangka meningkatkan modul pada interaksi tempat kerja harian, penyesuaian dapat dilakukan apabila dibutuhkan. Yaitu, jika evaluasi pasca-program menunjukkan tren jika, misalnya sejumlah besar peserta pelatihan mengatakan bahwa mereka mencoba tetapi masih berjuang, kemudian program pelatihan diubah untuk meningkatkan hasil.

Hingga saat ini, Tim Pembelajaran TI telah mengumpulkan data selama 1 tahun dari evaluasi. Dari hasil menunjukkan bahwa hanya $25 \%$ dari peserta pelatihan yang menyatakan bahwa mereka tidak ingat atau belum menerapkan salah satu strategi atau teknik yang disajikan, dengan demikian dapat dikatakan modul komunikasi antar pribadi cukup sukses.

Ke depan, Tim Pembelajaran berencana untuk meningkatkan kemampuan para pelatih untuk memperkuat pelatihan. Sumber daya yang terbatas membuat sulit menempatkan pembelajaran pada sistim formal, tetapi filosofi mereka menyatakan bahwa $50 \%$ dari nilai pembelajaran apapun berasal dari implementasi pasca pembelajaran. Sementara, $25 \%$ lainnya datang dari pelatihan dan umpan balik manajer. Hanya $25 \%$ saja dari nilai yang berasal dari waktu yang dihabiskan di kelas. Salah satu strategi yang sedang dikembangkan untuk mendapatkan dukungan pengawas adalah membuat peta dampak yang akan memberi tahu pengawas tentang tujuan modul pelatihan dan kemudian dapat memberikan usulan yang berguna untuk memperkuat hasil pembelajaran.

Pada skala yang lebih besar, Tim Pembelajaran sedang mengembangkan model pembelajaran campuran untuk itu program pelatihan. Menurut model ini, kelas tatap muka (atau virtual) dianggap sebagai memulai permulaan langsung. Dalam 2 bulan setelah kelas, peserta pelatihan diminta untuk berpartisipasi dalam serangkaian sesi interaktif online, seperti blog topik, tanya jawab telepon singkat (QnA), simulasi, diskusi, dan tugas kelompok. Kegiatan ini dapat dipimpin oleh seorang manajer senior, tetapi bukan pelatih profesional,. Tujuan dari kegiatan tersebut adalah membangun kesadaran diri dan penguatan pembelajaran. Manfaat dari model blended learning adalah siswa memiliki komitmen terhadap waktu, serba mandiri, dan memiliki fleksibelitas yang membangun keterampilan peserta pelatihan. Selanjutnya, model ini juga memberikan keterampilan kepada manajer senior dan manajer proyek yang memimpin pelatihan.

Perusahaan seperti yang dijelaskan di sini dapat dijadikan contoh nyata untuk analisa dan diskusi tentang peran komunikasi antar pribadi dalam bisnis pada kelas komunikasi bisnis. Studi kasus adalah alat pembelajaran yang diterima secara luas di sekolah bisnis, tetapi profesor komunikasi bisnis tidak boleh sering menggunakannya. Asosiasi Komunikasi Bisnis (ABC) memiliki catatan studi kasus. Pada tahun 1998, misalnya, jurnal yang disponsori ABC, Bisnis Communication Quarterly, menerbitkan edisi khusus tentang bisnis dan manajemen kasus komunikasi. Masalah ini termasuk 15 kasus yang relevan dengan komunikasi di tempat kerja, cocok untuk program sarjana dan pascasarjana. Kasus-kasus tersebut dilengkapi dengan catatan mengajar dan dokumen sampel siswa. Dalam edisi khusus pengantar, Rogers and Rymer (1998) mencatat manfaat utama dari studi kasus:

1. Kasus memberikan konteks untuk berkomunikasi

2. Kasus memungkinkan pembelajaran aktif

3. Kasus menghadirkan komunikasi sebagai tindakan social

4. Kasus menunjukkan sifat komunikasi kolaboratif

5. Kasus menggabungkan topik khusus seperti antarbudaya dan etika

6. Kasus menunjukkan efektivitas komunikasi sebagai kontingen 
7. Kasing menawarkan pandangan untuk menguji teori dan model.

Rogers dan Rymer (1998) menyimpulkan bahwa "pedagogi dan penelitian kasus sangat bagian penting dari kegiatan disipliner". Tahun berikutnya, Komite Pengajar ABC mensponsori kolom di Komunikasi Bisnis Quarterly yang menjelaskan cara menggunakan kasus di kelas kami (Dyrud \& Worley, 1999). Kolom menyediakan beberapa contoh, mulai dari teoretis ke pragmatis. Ini menawarkan sumber daya untuk lebih banyak kasus, baik pendek maupun komprehensif, termasuk situs web yang berguna dan sumber daftar pustaka yang berhubungan dengan metode kasus.

Implikasi kedua dari penelitian ini adalah komunikasi antarpribadi tampaknya sama atau lebih penting daripada menulis bisnis atau membuat presentasi profesional dalam kurikulum bisnis. Selama 30 tahun terakhir, literatur telah secara konsisten menunjukkan bahwa perekrut menganggap keterampilan komunikasi seorang kandidat merupakan kriteria paling penting untuk perekrutan (Hopkins, et al., 2011; Velasco, 2012). Sebuah studi oleh Kirmer \& Sellers (2009) berusaha untuk mengklarifikasi perekrut keterampilan komunikasi mana yang paling dihargai. Setelah menganalisis respons survey dari 94 perekrut di kampus, Kirmer dan Seller menemukan bahwa keterampilan komunikasi lisan, berbicara formal, kerja tim, komunikasi interpersonal, dan mendengarkan diberi peringkat tertinggi.

Hynes dan Sigmar (2009) juga mengadakan survei ke sekitar 100 kampus perekrut mewakili 45 bisnis dan lembaga pemerintah untuk menentukan kepentingan relatif dari berbagai keterampilan komunikasi. Hasilnya konsisten dengan studi yang dijelaskan sebelumnya dalam paragraf ini. Perekrut menilai kursus dalam hubungan tempat kerja seharihari dan komunikasi tim merupakan hal yang lebih penting untuk meraih kesuksesan di perusahaan dibandingakan kursus dalam menulis bisnis, presentasi, teknologi, dan komunikasi bisnis antarbudaya. Job Outlook 2012, sebuah nasional survei perekrut yang selenggarakan oleh Asosiasi Nasional Perguruan Tinggi dan Pengusaha, juga menemukan bahwa "kemampuan berkomunikasi secara verbal dengan orang-orang di dalam dan di luar organisasi "mempunyai peringkat lebih tinggi (\# 2) daripada kemampuan untuk menulis laporan (\#9) pada daftar keterampilan penting yang harus dimiliki karyawan baru (Koc, 2011).

Perusahaan yang diprofilkan di sini berfokus pada peningkatan komunikasi antarpribadi pada tenaga kerja IT-nya. Namun demikian, penelitian menunjukkan bahwa pekerja di semua industry dan bisnis, bukan hanya IT, dapat mengambil manfaat dari pelatihan komunikasi. Pusat untuk Profesional Terkemuka di York College of Pennsylvania mengadakan survey tahunan kepada lebih dari 600 profesional sumber daya manusia dan pemimpin bisnis untuk mengukur persepsi mereka tentang karyawan entry-level mereka. Hasil survei 2012 mengatakan mayoritas percaya karyawan baru mereka kurang profesional. Sifat-sifat yang paling sering di ungkapkan oleh responden sebagai karakteristik karyawan professional adalah "keterampilan interaksi pribadi, termasuk sopan santun dan rasa hormat" (34\%), dan "kemampuan mereka berkomunikasi, termasuk keterampilan mendengarkan "(25\%). Demikian pula di antara sifat-sifat yang di anggap oleh responden "tidak profesionalisme" adalah "keterampilan komunikasi yang buruk, termasuk tata bahasa yang buruk "(21\%; Pusat Profesional Terkemuka di YorkCollege of Pennsylvania, 2012, hlm. 19-24). 
Sejak kurang dari setengah responden survei dalam studi York College melaporkan bahwa perusahaan mereka memiliki program pelatihan tentang perilaku profesional, hasil ini menyiratkan bahwa perguruan tinggi harus berusaha untuk menumbuhkan profesionalisme di antara siswa mereka. Dengan demikian, kursus komunikasi interpersonal tampaknya sesuai untuk siswa yang mempersiapkan karir bisnis. Program sarjana bisnis hanya menawarkan satu atau dua kursus secara tertulis dan berbicara formal, sementara kursus komunikasi antar pribadi atau interaksi tempat kerja sehari-hari jarang.

Implikasi ketiga dari penelitian ini adalah profesional komunikasi bisnis seharusnya mempertimbangkan untuk ikut berpartisipasi dalam kegiatan konsultasi dan pelatihan perusahaan. Barker dan Camarata (1998) berpendapat bahwa komunikasi adalah komponen penting dari organisasi pembelajaran, dan profesional komunikasi bisnis itu harus berkomitmen untuk membantu organisasi tersebut mencapai tujuan tersebut. Barker dan Camarata mempresentasikan studi kasus dari suatu organisasi yang menggunakan komunikasi dalam membangun hubungan sebagai upaya untuk tetap menjadi organisasi pembelajaran. Implikasi dari penelitian mereka termasuk kelas komunikasi dapat memainkan peran utama dalam mengembangkan apresiasi siswa dan penerimaan organisasi pembelajaran dengan terus menyediakan yang diperlukan teori dan keterampilan dari perspektif berbasis hubungan. Profesor komunikasi mendorong pandangan yang terintegrasi tentang organisasi, perusahaan, manajerial, dan komunikasi bisnis yang dapat menghasilkan pembelajaran generatif yang diperlukan untuknorganisasi dan anggota besok.

\section{KESIMPULAN}

Penelitian ini menggambarkan sebuah perusahaan yang berbasis di AS yang mendedikasikan sumber daya yang cukup besar untuk peningkatan keterampilan bahsa dan komunikasi karyawan, khususnya keterampilan komunikasi antarpribadi mereka. Tiga implikasi nyata dari penelitian ini relevan untuk komukasi bisnis profesional: (a) contoh analisa bisnis yang sebenarnya merupakan aktivitas dalam kelas yang berharga, (2) siswa perlu mengenali peran interaksi tempat kerja sehari-hari terhadap produktivitas dan kepuasan kerja, dan (3) perusahaan mendapat manfaat dari layanan konsultasi para ahli di bidang bahasa dan komunikasi bisnis. Perusahaan yang mengakui sentralitas dan kekritisan kompetensi komunikasi antarpribadi untuk produktivitas dan keterlibatan tenaga kerja. Mempelajari kasus bisnis aktual menunjukkan pentingnya komunikasi untuk menginformasikan pengajaran kami. Pendidik komunikasi bisnis yang bekerja sama dengan perusahaan dan organisasi lain membantu meningkatkan dunia bisnis tempat kami mengirim siswa.

\section{DAFTAR PUSTAKA}

Amabile, T., \& Kramer, S. (2011). The progress principle: Using small wins to ignite joy, engagement, and creativity at work. Harvard Business Press.

Barker, R. T., \& Camarata, M. R. (1998). The role of communication in creating and maintaining a learning organization: Preconditions, indicators, and disciplines. The Journal of Business Communication (1973), 35(4), 443-467. 
Center for Professional Excellence at York College of Pennsylvania. (2012). Professionalism in the Workplace Study. Retrieved from http://www.ycp.edu/media/yorkwebsite/cpe/2012-Professionalism-in-the-Workplace$\underline{\text { Study.pdf }}$

Cross, R. L., Cross, R. L., \& Parker, A. (2004). The hidden power of social networks: Understanding how work really gets done in organizations. Harvard Business Press.

Dyrud, M. A., \& Worley, R. B. (1999). Focus on teaching: Using cases. Business Communication Quarterly, 62(4), 75-92.

Herzberg, F. (2008). One more time: How do you motivate employees?. Harvard Business Review Press.

Hopkins, C. D., Raymond, M. A., \& Carlson, L. (2011). Educating students to give them a sustainable competitive advantage. Journal of Marketing Education, 33(3), 337-347.

Hynes, G., \& Sigmar, L. (2009, April). The importance of business communication courses in employer hiring decisions. In First Annual General Business Conference Conference Proceedings (p. 193).

Ihani, W., Syofya, H., Sari, A. L., Mulawarman, W. G., \& Sriyanto, S. (2020). The Role of the Creative Industry in Economic Development. Journal of Environmental Treatment Techniques, 8(1), 268-271.

Kirmer, R., \& Sellers, J. A. (2009, February). How current is your BCOM course. In Association for Business Communication Southwestern US Annual Conference, Oklahoma City, OK.

Koc, E. W. (2011). Getting noticed, getting hired: Candidate attributes that recruiters seek. NACE Journal, 72(2), 14-19.

Lim, S., Cortina, L. M., \& Magley, V. J. (2008). Personal and workgroup incivility: impact on work and health outcomes. Journal of applied psychology, 93(1), 95.

Mat, N. H. N., \& Zabidi, Z. N. (2010). Professionalism in practices: a preliminary study on Malaysian public universities. International Journal of Business and Management, 5(8), 138.

Polk-Lepson Research Group. (2012). Professionalism in the workplace study. Center for Professional Excellence at York College of Pennsylvania, York, PA.

Reinsch Jr, N. L., Gardner, J. A., \& Berland, P. S. (2011, October). Do good communicators get promoted? Maybe not. In Proceedings of the 76th annual convention of the Association for Business Communication. Retrieved from http://businesscommunication.org/wp-content/uploads/2011/10/2011-ABC-01REINSCH.pdf.

Riketta, M. (2008). The causal relation between job attitudes and performance: a metaanalysis of panel studies. Journal of Applied Psychology, 93(2), 472.

Rogers, P. S., \& Rymer, J. (1998). Business and management communication cases: Challenges and opportunities. Business Communication Quarterly, 61(1), 7-25.

Sandelands, L. E., \& Boudens, C. J. (2000). Feeling at work. Emotion in organizations, 2, 4663.

Tucker, M. L., Powell, K. S., \& Dale Meyer, G. (1995). Qualitative research in business communication: A review and analysis. The Journal of Business Communication (1973), 32(4), 383-399.

Velasco, M. S. (2012). More than just good grades: candidates' perceptions about the skills and attributes employers seek in new graduates. Journal of Business Economics and Management, 13(3), 499-517. 